\title{
The Construction and Practice of Quality Monitoring and Guarantee System on Experiential Foreign Language Teaching in Local Colleges and Universities*
}

\author{
Guiying Kong \\ International Exchange College \\ Wuzhou University \\ Wuzhou, China 543002
}

\begin{abstract}
Teaching quality is the fundament relying for survival and development of colleges and universities. On the grounds of the teaching conditions, the concept of experiential teaching, learning feature and the connotation of experiential process, the foreign language teaching should construct such entity operations taking students, teachers, management as the centers and at same time build three parallel running routes of teaching quality monitoring and guarantee system. The three parallel running routes would fully implement to the specific steps of experiential teaching such as before-class, class, afterclass, practice and innovation to form a flexible, dynamic, fully participating and suitable for foreign language teaching activities to carry out the quality monitoring and guarantee system so as to finally realize the improvement of foreign language teaching quality in local colleges and universities.
\end{abstract}

Keywords-local colleges and universities; experiential foreign language teaching; quality monitoring; guarantee system

\section{INTRODUCTION}

The concept of experiential foreign language teaching is based on the constructivism teaching theory, cognitive teaching theory, modern teaching view and Bruner's discovery learning mode. Experiential learning emphasizes the process of individual learner's participation in learning activities, focuses on the continuous updating of individual learner's own experience to achieve the reconstruction of knowledge. Experiential teaching puts individual into the

*The paper is:

1. Phase result of the General project category A of Guangxi higher educational undergraduate teaching reform in 2017 "The Innovation and

Practice of Talent Cultivation Mode on Experiential Foreign Language Teaching in Local Universities", project number: 2017JGA309.

2. Major project of Wuzhou university-level educational teaching reform in 2016: "The Construction and Practice of Quality Monitoring and Guarantee System on Experiential Foreign Language Teaching in Local Universities", project number: Wyjg2016A001.

3. Phase result of the key research base on humanities \& social sciences in Guangxi universities -- The research Center of Folk Literature in Xijiang River, (project number: Guangxi Educational Scientific Research [2014] 12).

4. Funded by "Youth Backbone Teachers' Training Program" of Wuzhou University. language learning center; focuses on individual needs and personalized learning; pays close attention to individual learner with their classmates, teachers, communication, collaboration and integration of learning contents; and emphasizes on classroom teaching situation and reenactment of realistic scenes in and out of school[1] Experiential teaching pays more attention to individual's autonomous exploration, experience and the cultivation of the innovative applications. Environment, experience, practice and undergoing are essential elements of experiential teaching. Individuals, with their classmates, will understand deeply the contents, method and effect of knowledge through their experience, practice and undergoing of simulation environment, which manifests the independent, flexible, open, comprehensive, innovative learning characteristics. Therefore, on the basis of the concept of experiential teaching, learning, characteristics and the connotation of process of experience, the foreign language teaching in local colleges and universities can build the foreign language learning environment which is more beneficial for students to carry out their experience, practice, innovation, application, thus also to build a more flexible, dynamic, efficient operation and management which can not only be suitable for local colleges and universities to realize their transformation development, but also to close integration with foreign language teaching and learning activities between teachers and students of the quality monitoring and guarantee system.

\section{THE COMPOSITION AND OPERATION OF THE QUALITY MONITORING AND GUARANTEE SYSTEM OF EXPERIENTIAL \\ FOREIGN LANGUAGE TEACHING}

The quality monitoring and guarantee system of experiential foreign language teaching includes the quality monitoring, evaluation and guarantee, teaching quality standards and inspections, information collection and feedback, organization and management, etc. These departments and persons such as vice president, teaching guiding committee, office of academic affairs, associate deans of subordinate college, teaching and research office, 
teachers and students, off-campus tutors, supervisors, inspectors, information-feedback of students are involved in this system.

The functional operation of experiential foreign language teaching quality monitoring and guarantee system will form three lines into the concrete experiential teaching process. The first line is the students' self-experience learning process management of teaching quality monitoring and guarantee, this is, the students are responsibility for their self-discipline, monitoring and management in their own experience of preclass, class, after-class, practice and innovation of the application. Using the individual students as the subjects of their self-learning management and monitoring is the most prominent teaching quality monitoring and guarantee features of experiential foreign language teaching in local colleges and universities. The second one is the course teachers' self-monitoring and management of the whole teaching process of their own foreign language courses and the teaching quality monitoring, management and guarantee of the students' entire foreign language experience. This line contains two levels, namely one is the teachers for their own foreign language teaching quality management and constraints, another is the teachers for students experiential learning of monitoring and management. This is another feature of experiential foreign language teaching quality monitoring and guarantee in local colleges and universities. The last one is referring to the monitoring of management entity such as the heads of teaching and research office, associate deans of subordinate college, and the supervisors of the academic affairs office, the line is more reflected on the support for the first two lines of teaching monitoring, adjust and control, teaching guarantee. The three lines run at the same time. In addition, local colleges and universities will follow up experiential foreign language teaching quality through using information-feedback of students, tutors, inspectors, supervisors and other auxiliary information reporting, spot check and monitoring, assessment and evaluation of teaching guarantee way.

\section{THE OPERATING PRACTICE OF THE QUALITY MONITORING AND GUARANTEE SYSTEM OF THE \\ EXPERIENTIAL FOREIGN LANGUAGE TEACHING IN LOCAL COLLEGES AND UNIVERSITIES}

The core of the quality monitoring and guarantee of experiential foreign language teaching is the whole process of students' experience of foreign language learning and the teachers' teaching and managing process which will be closely integrated into the students' experience of beforeclass, class, after-class, practice and innovation in the application. In general, several experiential learning steps can be divided into the roles of experiential leading off before-class, experiential participation in class, experiential thinking of after-class, experiential mutual promotion on campus, experiential application and innovation out of school, the teaching management and evaluation system, etc.

\section{A. The Route of Students' Self-policing to Experiential Learning Process}

Students are the core of the entire experiential foreign language teaching, their interests in learning and selfmanagement will directly affect the improvement of foreign language teaching quality. During the experiential leading process before class in foreign language classes, students will receive the requirements of the teaching content from the course teachers, then they will experience the corresponding learning activities according to different requirements of the course teachers. To the process of the experiential participation in class, students will carry out these activities such as simulating practice of situational roles, organization of language contexts, investigating reports, reporting compilation of data in the classroom according to their own experience prepared before class so that experiential contents in individuals, groups' discussion, communication and collaboration will be improved. In the comments of classmates and teachers, the knowledge of individual students' experiential activities will be corrected. To the process of experiential thinking of after-class and experiential mutual promotion on campus, individual students will take their thinking from the experiential roles to finish sets of professional homework, practices or quizzes. What individual students do in this process will help them to further improve the knowledge of cognitive and consolidate their experiences. Then, individual students will simulate experiential activities at school again, these activities include English corners, chatting in tea rooms, communicating with oversea students, international cultural festivals, school foreign affairs activities, etc. They also can take part in these activities such as foreign language speech, poetry reading, dubbing, singing, translation, business, planning contest, etc. With these earlier stages of experiences, individual students can participate in the activities of experiential application and innovation out of school as the roles of individuals, teams, research groups and classes. They may practice in local schools which cooperate with enterprises, or give lessons in primary and subordinate colleges, training institutions at home and abroad, or practice in news agencies, publishing houses, foreign affairs departments, and hotels and other relevant jobs, or practice in the joint ventures, foreign-funded enterprises, foreign-related companies, etc. With these practice exercises, individual students can integrate their foreign language knowledge into consolidation and application innovation of practical experience. In addition, college students' innovation and entrepreneurship programs, innovative experimental projects, foreign language teaching research and dialect research can also help them to apply innovation in language experience. In the part of teaching management and evaluation, firstly, individual students will truthfully fill in their own experiential contents, real experiential harvests, scores and summaries in active records and achievement evaluation form after completing each concrete content. Secondly, the group members of individual students will give their evaluation according to the specific performance of individual students' experiential activities. Thirdly, other groups will give their members' assessment to the individual students' learning experiential behavior. In APP, UMU or 
network teaching management platform system, they will also record the professional trainings and test results in each unit which completed by individual students, and individual students can check and correct themselves at any time.

\section{B. The Route of Teachers' Monitoring to Experiential Learning Process}

The teachers of experiential foreign language teaching are the main supervisors, implementers and guarantors of the quality and guarantee system of experiential foreign language teaching, as well as the leaders of the process of teaching quality objectives. For foreign language classes, the teachers provide teaching classes with activation records and result evaluation tables of experiential learning, these tables can be the paper, electronic version and management platform system having the date, name, experiential learning content, content of application and innovation, harvest and summary, evaluation and so on. The tables can also record students' self-evaluation of each experiential activity, the evaluation of their own group members and other groups members. Usually, the students in the teaching classes are divided into several groups of 4-5 so as to facilitate them communication and collaboration, each group has a group leader, who is responsible for the activity evaluation records of his own group and other groups. In addition, the class committee and the team leaders have more record tables to register students' scores in each unit about their dictations, compositions, pop quizzes and the attendances [2]. Using the convenient conditions of students having mobile phones, through QQ, Wechat, email, Mook, flipped class, APP, UMU and network teaching management platform system, the teachers send the experiential contents of each unit to individual students and tell them what they need to pay attention to; the teachers also provide relevant learning data such as PPT coursewares, websites, references, the experiential practice records of previous outstanding students. When individual students finish their each experiential step, they send their exercises, summaries and scores of selfevaluation to the group leader, the group leader uploads them to the class Wechat, APP, UMU learning records created by class libraries, all kinds of learning materials can be shared, inquired by each student in the class, which makes it easier for teachers to supervise and spot check each student in dynamic learning. During the process of each experience, the teachers give their explanations and guidance of the problems encountered by students on QQ, Wechat, APP, UMU and other online platforms. In the experiential activities in classroom, campus or outside of school, the teacher will be highly close communication with individual students and guide them how to do at any time. The teachers require individual students to shoot their key experiential points, upload them to the class learning records so that all students can consult, remark and learning. By the end of the term, the teachers and all teams assess individual students in their experiential activities records and performance evaluation forms, the marks occupy $30 \%$ of the overall rating, individual students' dictations, exercises, quizzes and attendances in each unit occupy $10 \%$, and the final exam results occupy $10 \%$, all formative learning evaluations will form individual students' learning result of final evaluation.
At last, the teachers hand in students' final evaluations to the school's teaching secretariat, then secretariat will submit the evaluations to the office of academic affairs [3].

\section{The Route of Management Entity to Monitoring and Guarantee System}

The quality monitoring and guarantee system of experiential foreign language teaching is attached to the school's management of quality monitoring and guarantee system, its implementation must rely on the control and security of the subordinate college, teaching and research sections. The quality standard of experiential foreign language teaching made by the subordinate college and its subordinate teaching and research sections, foreign language teachers including professional and college English teachers must accord with the training orientation of the school. They should not only build the training objectives, specifications and programs of experiential foreign language teaching, but also set up normative documents of professional construction and curriculum setting, construct the innovative team of experiential foreign language teaching to ensure the foreign language teaching quality, which belongs to the teaching quality standard system. In the experiential teaching, the teaching and research sections require their teachers to write the courses syllabus of experiential foreign language, cooperate with office of academic affairs to check teachers' preparations, teachings, homework assignments and correcting, paper propositions, etc. In addition, the teaching and research sections still shoulder the checking management of teaching quality specification such as contents of courses, implementation of teaching contents, teaching plans for teachers, classroom discipline, experiential time and contents, the project progress of students' scientific research and so on, which belong to teaching quality inspection system. In the extracurricular practice, office of academic affairs, subordinate college, teaching and research sections need contact with other schools, companies, institutions and other units for students so as to help teachers to arrange individual students to experience and practice, and to help teachers to make experiential contents, time, evaluations and quality standards at the same time, which belong to the quality monitoring, evaluation and guarantee system. Through the ways of inspection, monitoring, evaluation and feedback, the subordinate college and teaching and research sections test their experiential foreign language teaching quality standard, then feedback their results of each teaching process to organizational management entity system, teachers and students. Teachers and individual students continuously improve their quality according to the feedback information which belongs to information collection and feedback system. Organizational management system is mainly responsible for the formulation and operation mechanism of the school's teaching quality monitoring and security system including the experiential teachings; making management goals, standards, policies, measures, coordination of the teaching department activities of the school teaching quality. The teaching staff of subordinate college, teaching and research sections is responsible for the specific teaching inspecting work and implements the school teaching quality monitoring 
and guarantees system which belongs to organizational management system.

\section{THE OPERATING PRINCIPLE OF THE QUALITY MONITORING AND GUARANTEE SYSTEM OF EXPERIENTIAL FOREIGN LANGUAGE TEACHING}

The operation of the quality monitoring and guarantee system of experiential foreign language teaching embodies the principle of all-people participation, dynamic activation and full process. The improvement of foreign language teaching quality is not only connected with school's orientation, talent training objective, management system, but also closely connected with the various functional departments of school, the subordinate college, teaching and research sections. What's more, it still involves in teachers and students, teaching staff, teaching facilities, teaching conditions, etc. All these elements present a pattern of multilevel, intersect and full participation. In this pattern, the individual students are as the main regulators of experiential teaching during the specific process of before-class, class, after-class, practice and innovation. In each process, it accompanies with individual students, the groups, other groups, class committees, teachers, teaching systems, practices, experiences, tests and learning evaluation records which making experiential foreign language teaching quality monitoring present the principle of dynamic, flexibility and diversification. The improvement of teaching quality is mainly formed in the concrete teaching process; its quality monitoring system is monitoring the whole experiential foreign language teaching and learning specific details to do a good job in the whole teaching control and management. Therefore, foreign language teachers as the guiders and supervisors of the process of teaching and learning should mutual cooperate and mutual support with other staff members and departments for the specific teaching experience of students to provide security.

\section{CONCLUSION}

Teaching quality is the fundament relying for survival and development of colleges and universities, the development of foreign language teaching in local colleges and universities will be influenced by its geographical location, school-running level, scale, teaching resources and other factors, thus further affect the improvement of the overall teaching quality. The foreign language teaching in local colleges and universities should fully understand the experiential teaching of concept, characteristics and experiential learning to build a route for students to experience the self-monitoring of learning process; a route for teachers' teaching and learning of the monitoring and management; and a route for management entity to monitoring and guarantee system. These routes are closely integrated into before-class, class, after-class, practice and innovation in the application of students' experience so that the experiential foreign language teaching quality monitoring and guarantee system can present such characteristics of allpeople participation, dynamic activation and full process. The teaching evaluation therefore form an objective and fair, diversified characteristics, as a result, experiential foreign language teaching in local colleges and universities can run its quality monitoring and guarantee system into the process of teaching and learning of specific details in foreign language teaching of monitoring and management so as to improve the foreign language teaching quality in local colleges and universities.

\section{REFERENCES}

[1] Yu Feng. An overview of experiential English teaching[J]. Journal of Yichun University, 2012(6):148-151.

[2] Guiying Kong. Empirical study on the influence of experiential foreign language teaching on teaching management and evaluation system----taking International Exchange College of Wuzhou University as an example[J]. Journal of Guangxi Open University. 2017 (1) : 69-73. 